\title{
NARRATIVE MODELLING OF AMERICAN AND AUSTRALIAN FAIRY NARRATIVES FOR CHILDREN IN A CULTURAL PERSPECTIVE
}

\section{Tsapiv A. O.}

\section{INTRODUCTION}

Narration as a widespread speech activity can be observed in many spheres of life: in everyday conversation when one speaks about some experience as a sequence of events story, one can hear narratives on TV when a reporter tells us something based on cause-and-effect relationships. Narratives are the stories that we read to our children for the bedtime. Human brain is constructed in such a way that it captures complex reality, experience, life episodes in the form of narratives ${ }^{1}$. So, what is narrative? Narrative is a story about some events(s), presented as a sequence of events story, united by cause-and-effect relationships ${ }^{2}$. Narratologists try to create basic narrative explanatory models in order to understand the nature of storytelling ${ }^{3}$. How are the stories created? If there exists a set of typically structured stories with a number of participants and settings, there should be some abstract patterns in their background.

The first scholar, who suggested to the philological world explanatory patterns, underlying Russian folktales, was Vladimir Propp. In his Morphology of the Folktale $e^{4}$ the author explains a typical structure of a folktale (here fairy folktales are meant), which follows the chronological order of the linear sequence of elements in the text as reported from an informant (i.e. it means the syntagmatic structure). Another pattern of a paradigmatic nature was suggested by Propp's opponent Claude LeviStrauss 5 . He proposes that all possible pattern elements are taken out and regrouped in one of the analytic schema. Propp's functions refer to the building blocks of the tale's plot and correlate with typical characters of folktales. Propp understands functions as character's actions, defined from

\footnotetext{
${ }^{1}$ Fludernik M. Fludernik M. An introduction to narratology. London and New York : Rouledge. Taylor and Francis group, 2002. P. 1-2.

${ }^{2}$ Toolan Michael Making sense of narrative text. Situation, repetition, and picturing in the reading of short stories Taylor ans Francis Ltd., 2016. P. 32-36.

${ }^{3}$ Herman L., Vervaeck B. Handbook of narrative analysis. Lincoln and London : University of Nebraska Press, 2001. 232 p. Handbook of narratology / eds. Peter Huhn, John Pier, Wilf Schmid and Jorg Schonert. Berlin. New York : Walter de Gruyter, 2009. 468 p.

${ }^{4}$ Пропп В. Морфология сказки. Ленинград : “Academia”, 1928. 152 с.

5 Література. Теорія. Методологія / за наук. ред. Данути Уліцької. Київ : Видавничий дім “КиєвоМогилянська Академія", 2008. С. 219-225.
} 
the point of view of its significance for the course of the whole action: functions of characters serve as stable, constant elements in a tale, independent of how and by whom they are fulfilled. They constitute the fundamental components of a tale. The number of functions known to the fairy tale is limited ${ }^{6}$. These functions can occur in different combinations and create a chain of events which construct the whole narrative as a story about these events. Given that, the above mentioned functions (there are 31 of them) prove the existence of certain patterns which serve as a universal matrix for all folktales that exist in Russian linguistic culture.

In this research we assume that to realize the patterns that underlie a fairy tale of any linguistic culture and to understand cultural specificity of fairy narratives one needs to research both the text and its wide context (i.e. all extralinguistic factors that influenced its creation). Following Propp's ideas in our scientific work we have tried to create a matrix model that would both explain author's intentions and strategies, implemented in the text, and give methodological tool to make appropriate interpretation of the fairy narrative.

\section{Model of narration}

Narrative is a complex unit structure which unfolds into two basic components: narrative and narration ${ }^{7}$. We assume that narrative is a story about sequence of events syntagmatically or paradigmatically built. Narration refers to the process of constructing these events via verbal and/or nonverbal medium. Narration is the process of creating a fictional world with human or anthropomorphic characters who exist in fictional time and space and perform goal-directed actions ${ }^{8}$. In literary texts where verbal (sometimes visual) medium dominates, the text world is represented by a narrator, who functions as a mediator. A narrator shapes a story (narrative) by choosing all the building elements for it: focalization, narrative episodes, gives or does not give access to character's thoughts and plans.

It is assumed, that narrative, created for children, is constructed in a special way. Narration models the story so that it becomes interesting for a child reader. One can't deny the fact that literary texts for adult audience and for children differ and no one doubts in referring fairy tales to the category of children's literature and psychological thrillers to adult group. Though, genre is not the only criterion.

\footnotetext{
${ }^{6}$ Morphology of the Folktale by V. Propp / revised and edited by by Louis A. Wagner. Austin : Uneversity of Texas Press, 20019. P. 21.

${ }^{7}$ Женетт Жерар Фигуры . М. : изд-во им. Сабашниковых, 1998. С.310.

${ }^{8}$ Fludernik M. Fludernik M. An introduction to narratology. London and New York : Rouledge. Taylor and Francis group, 2002. P. 6.
} 
It is hypothesized in our research that the matrix, which underlies fairy narratives for children, is a game-model matrix. Unconsciously, when writing for children, the author goes back to his childhood in his thoughts ${ }^{9}$. Writers are well aware of the potential realization of the text by its implied reader (a child-reader), especially in regard to the following aspects (which, of course, are mutually dependent): the text's complexity, the structure of the narration, the stylistic level, and the subject matter ${ }^{10}$. So, the writer chooses the plot and builds the composition of a creative work addressed to children, basing on some principles: first, the plot should be simple, dynamic and comprise some mystery, some quiz, discovering which a child becomes curious, characters should be strictly divided into positive and evil, ambivalence is out of the question. Curiosity, brainteasers are the key narrative storybuilding elements, which are hidden in the plot of a fairy narrative. The best way of communicating with a child, teaching him something, providing with some new knowledge, presupposes playing a game with him/her. Psychologists claim, that game activities are the most productive and interesting for a child ${ }^{11}$. Playing games, a child learns how to behave with others, finds out new information, becomes active and develops critical thinking and imagination. Fairy narratives for children are construed in such a way, that definite narrative (chronotope, characters, events of the story) and narrational (composition structure, key-words in narrative episodes) triggers activate in a child's mind his/her knowledge about the game and make him/her immerse in the text.

\section{American literary fairy narratives}

American nation has got a reputation of being tolerant and democratic. All people are respected and have equal opportunities irrespective of their gender, nationality, skin color, religious beliefs and ideology. Amazing stories of famous people who had nothing, no money or help, and became famous and rich, prove that America is the country with democratic standards and big possibilities. There are inspiring real life stories of Steve Jobs, Elon Reeve Musk and many other inventors, who made their dreams come true. As it is known, Steve Jobs made a great contribution not only to the Apple Inc., but also into the Walt Disney Company and made Pixar

\footnotetext{
${ }^{9}$ Glazer J., Gurney Williams III Introduction to children's literature. New York : McGraw-Hill, 1979. P. 22.

${ }^{10}$ Shavit Z. Poetics of Children's literature. Athens and London: The University of Georgia Press, 1986. P. 42-43. Beauvais Clementine The mighty child. Time and power in children's literature. Benjamins. Amsterdam : Publishing company, 2015. P. 2.

${ }^{11}$ Выготский Л.М. Психология развития ребенка. Москва : Смысл; Эксмо, 2004. 512 с.
} 
animated cartoons highly technological and bright. It makes us think that the ideology of American dream, the stories about one's long way to success, overcoming obstacles, fighting with disbelief is anchored in the core of American people's mind, it creates a unique nation's mentality, free and brave.

American literary texts for children differ from any other fairy tales, they are not similar to English or Australian fairy narratives. Exploring a wide context of the development of American literary texts for children and texts of fairy narratives of different American authors, we have revealed certain tendencies in their model structure. In this paper we shall demonstrate the specificity of American narratives and the way of their construing (narration) on series of diary-format narratives "Diary of a Wimpy Kid".

\section{Diary of a Wimpy Kid. Digital era}

One of the most successful books for children in the USA is "Diary of a Wimpy Kid"12. Digital version of Wimpy Kid is daily read on Funbrain website by more than 70000 kids $^{13}$. In 2006 digital diary was turned into a print version. Now it has 73 editions in 61 languages, it has got lots of national and regional awards including Children's Choice Book Awards and Nickelodeon Kid's Choice Awards for favorite book.

The series of books about Greg Heffley, a schoolboy, who is funny and self-critical, became a real bestseller all over the world. Its creator Jeff Kinney made an absolutely unique diary of Greg, who puts down all his thoughts, plans, memories, hesitations, moments of disgust and success on the pages of his diary. Diary-format narrative episodes are narrated by means of verbal and visual (illustrational) forms i.e. verbal text is accompanied by lots of illustrations/illustrations with bubbles which sometimes dominate over the text.

Jeff Kinney is a designer and computer programmer, who didn't plan to become a children's writer. He had a desire to be a cartoonist ${ }^{14}$. His dream came true and was implemented on the pages of Greg's diary. Firstly, it had a digital version and was available on Funbrain website. Visually, it looks as a real notebook in line, as if written by hand. Any Funbrain user can turn the pages and get involved into Greg's life. Greg's story is a story about a schoolboy, who dreams, fails, makes friends, sometimes feels happy and sometimes disappointed.

\footnotetext{
${ }^{12}$ Kinney Jeff Diary of a Wimpy Kid. England : Puffin, 2010. 218 p.

${ }^{13}$ Diary of a Wimpy Kid. URL: https://www.funbrain.com/books/diary-of-a-wimpy-kid

${ }^{14}$ Diary of a Wimpy Kid. About the author. URL: https://wimpykid.com/about-the-author/
} 


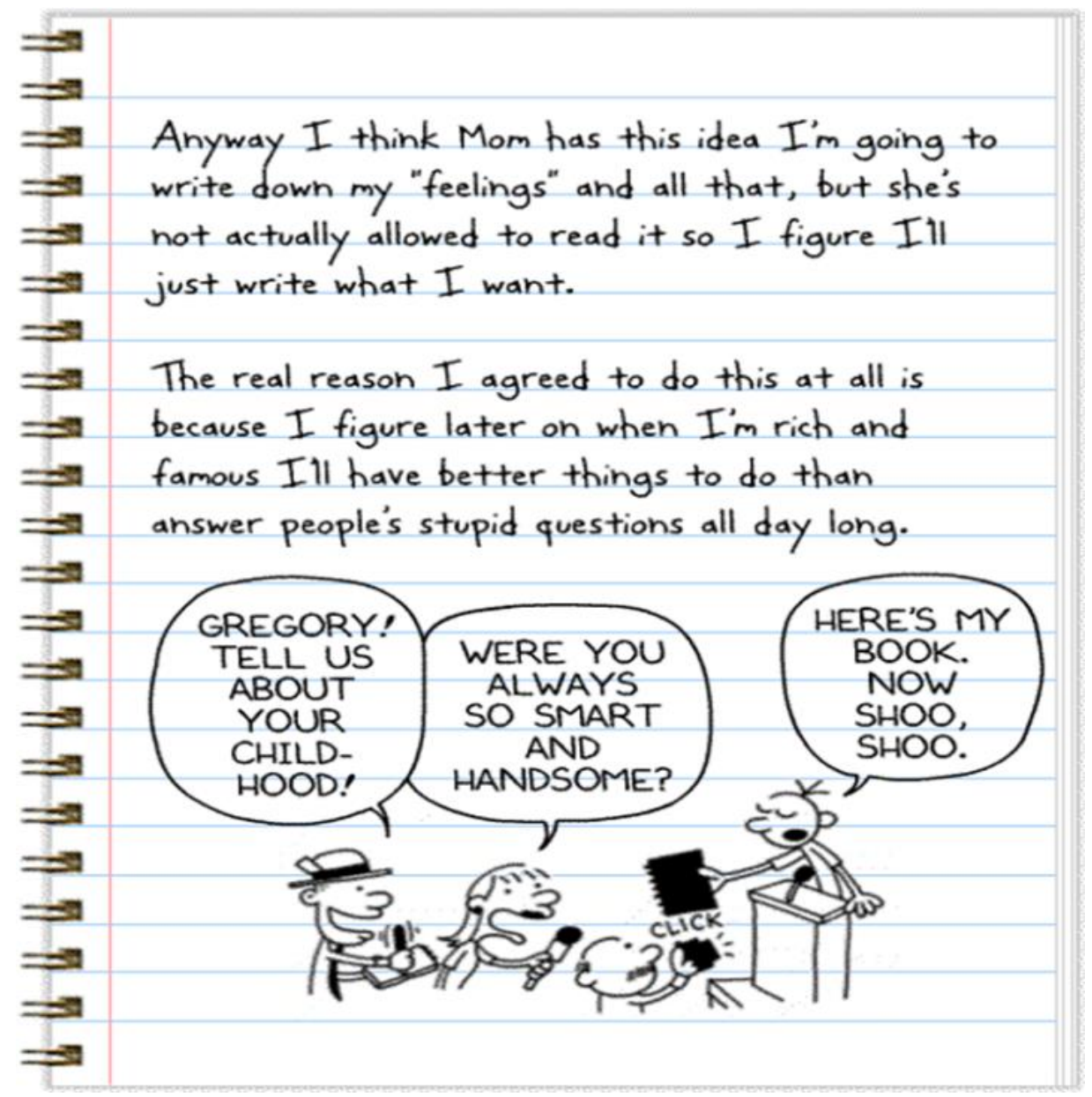

Fig. 1. Diary-format narrative "Diary of a Wimpy Kid"

The whole book is split into lots of narrative episodes (In our research we use the term narrative episode. It is assumed that narrative episode is an autosemantic textual/verbal-visual fragment, which conveys one event from the character's life, it has time and special definite boarders, and has a status of one constituent element in the chain of narrative events). Each episode conveys one event of Greg's life. It can be a school, family or personal scene, narrated by verbal and visual means.

While reading textual-visual (textual-graphical) narratives, readers (child-readers) comprehend the story encoding textual information and the message, realized in cartoon images. Cartoon images give the readers clues to extended, additional and detailed information, actualized via character's body language, facial expression, time and space settings. Cartoons often serve the platform to realize graphical metaphors, symbols, metonymies. For example, Greg has a school friend Rowley, who he finds a little bit absent-minded and slow. Rowley is represented in cartoons as a boy with square head and one ear. Square head, as it is commonly known, characterizes people with low intellectual skills. One ear serves a cartoon realization of the sense: goes in one ear and out of the other (Fig. 2). 


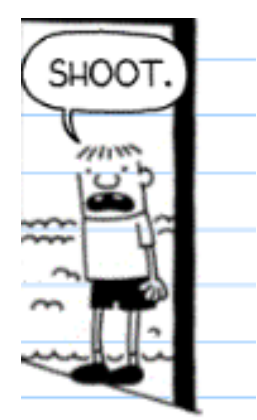

Fig. 2. Greg's friend Rowley ("Diary of a Wimpy Kid")

Verbal and visual narrative techniques construct the story and make it easily comprehensible for child-readers. All complexity (like long descriptions, monologs etc.) is often transferred into the cartoon/visual elements and thus, the verbal narrative becomes simplified. Both verbal and visual elements enable a child-reader to realize the entire story and become its creator either. One can make a narrative in his mind while decoding information from the illustration. Readers logically connect all the elements, verbally or visually realized, into one narrative. All the elements like jigsaw puzzle pieces create one entire story. For example, in a narrative episode of Greg's school experience, verbal information conveys some facts about neighbors, who sit in front (Chris Hosey) and back (Lionel James) of Greg.

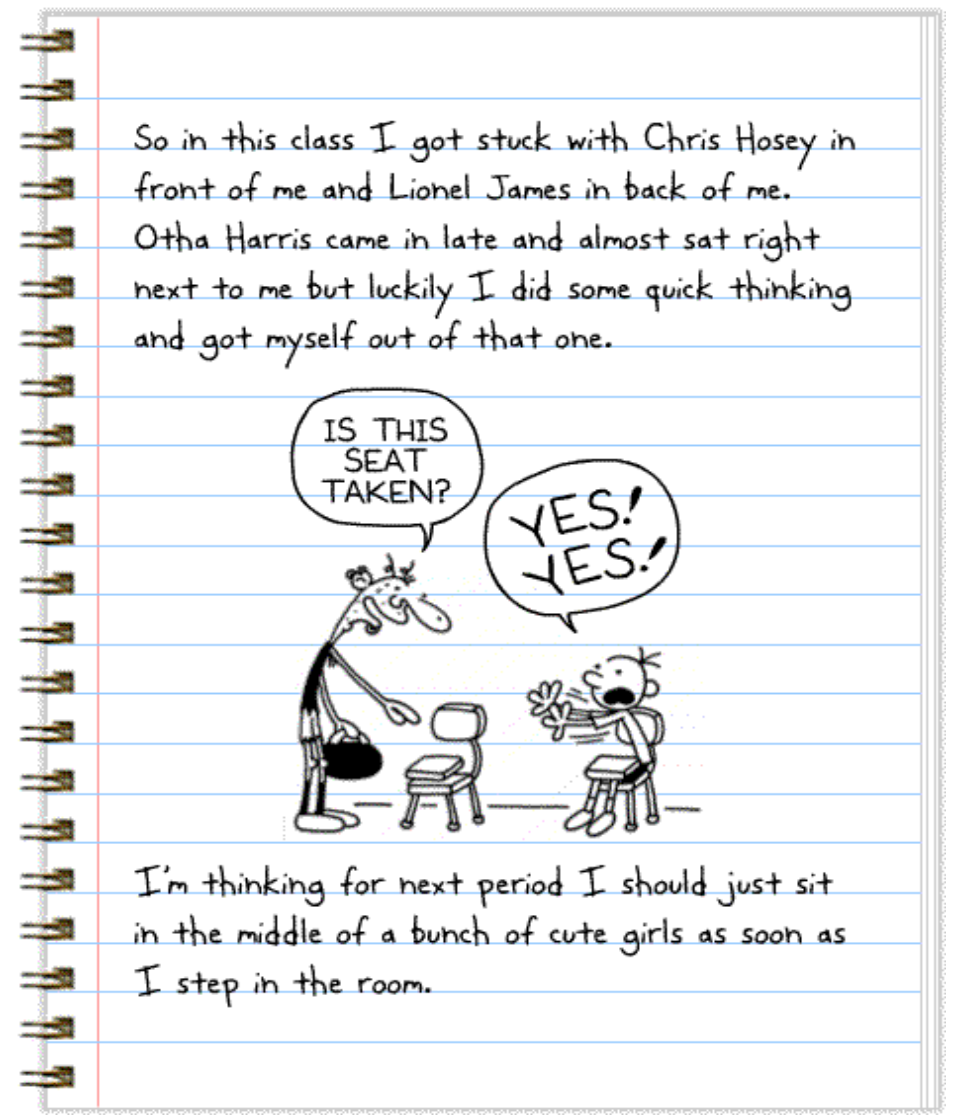

Fig. 3. Narrative episode of Greg's school life experience 
The nature of such visual-verbal narrative episodes can be interpreted regarding C.S. Pierce triad of signification (symbol, icon, index). Speech bubbles is the combination of symbolic (it represents the idea of a speech act) and indexical (it makes a link between the speaker and what definitely he says) semiotic signs ${ }^{15}$. The illustration itself is a complex narrative visual-verbal episode as it possesses semiotic signs (both conventional and non-conventional), textual and graphical elements. Emotional excitement of Gregg is realized via speech bubbles. Word's capitalization and a question mark define anxiety (YES! YES!), his gestures (hands are pulled forward), facial expression (his mouth is widely open as if producing loud sounds) manifest his emotional answer on Otha's question. Textual narration provides the reader with general information about Greg's unwillingness to sit near Otha (Otha Harris came late and almost sat right next to me, but luckily I did some quick thinking and got myself out of that one). The cartoon illustration gives readers explanation of Greg's actions. To be more precise, Otha's appearance gives clues to the readers. She looks ugly, as she has pimpled face, long nose, odd curling two hair strands, she is a bit clumsy and odd-looking. Summing up, the message of the narrative episode, decoded from the cartoon and speech bubbles - Otha Harris wanted to sit near Greg and asked for the permission, but Greg found her odd and ugly, he was against it, that's why he emotionally and loudly told Otha that the seat near him wasn't vacant.

In this episode Greg, as I-narrator, manifests his own experience and feelings/emotions that accompanied that episode of his life. Speech bubbles, as well as Greg's and Otha's cartoons, are visual-verbal means of expression Greg's thoughts. From the cognitive perspective I-narration in diary narratives provides the readers with the access into his (as the main character's) mind. A cognitive narratologist Alan Palmer in his book "Fictional minds" claims that novel reading is mind reading. One can't find out what real people feel or think, one can only guess. Fictional characters and their inner world can be accessed by narrator as an inner textual category, which constructs the narrative ("We never know them well, do we?" "Who?" "Real people." "What do you mean, 'real people'?”. "As opposed to people in books", Paola explained. "They're the only ones / we ever really know well, or know truly. ... Maybe that's because they're / the only ones about whom we get reliable information...Narrators never lie") ${ }^{16}$. A narrator can open the access into character's plans, memories, thoughts, emotional condition. In narrative situations (in terms of Franz

${ }^{15}$ Kukkonen K. Contemporary comics storytelling. Lincoln and London : University of Nebraska Press, 2013. $231 \mathrm{p}$.

${ }^{16}$ Palmer Allan Fictional minds. Lincoln and London : University of Nebraska Press, 2004. P. 1. 
Stanzel $)^{17}$ when narrator and focalizer meet at one point, it becomes possible. In diary-format narratives with I-narrator, the whole chain of events is manifested from the point of view of its narrator. The chain of events in Greg's diary is manifested verbally and visually by Greg as I-narrator. He represents his life experience emotionally, sentimentally, opens the readers access to his inner world. The whole diary narrative as if tells a life story of an ordinary boy who demonstrates that to be sometimes wimpy is typical for anybody. The diary demonstrates everyday fighting with obstacles and misunderstanding, Greg's self-ironical narration creates a unique narrative as a story about his life. Such narration of people's life stories are considered common for American narratives. Someone's life experience is embodied into a narrative as a humorous/ironical story.

The whole diary is construed of various verbal and verbal/visual episodes which we reconstruct and model as a jigsaw puzzle narrative. Thesaurus dictionary proves that jigsaw puzzle is a picture made of a lot of small pieces that you have to fit together ${ }^{18}$. Diary of a Wimpy kid is a narrative, modeled as a "great puzzle" and fitting together pieces of odd data (various narrative episodes of Greg's life) one can make a clear picture of a child's life story. One by one each episode completes the whole holographic picture of a certain period of Greg's life.

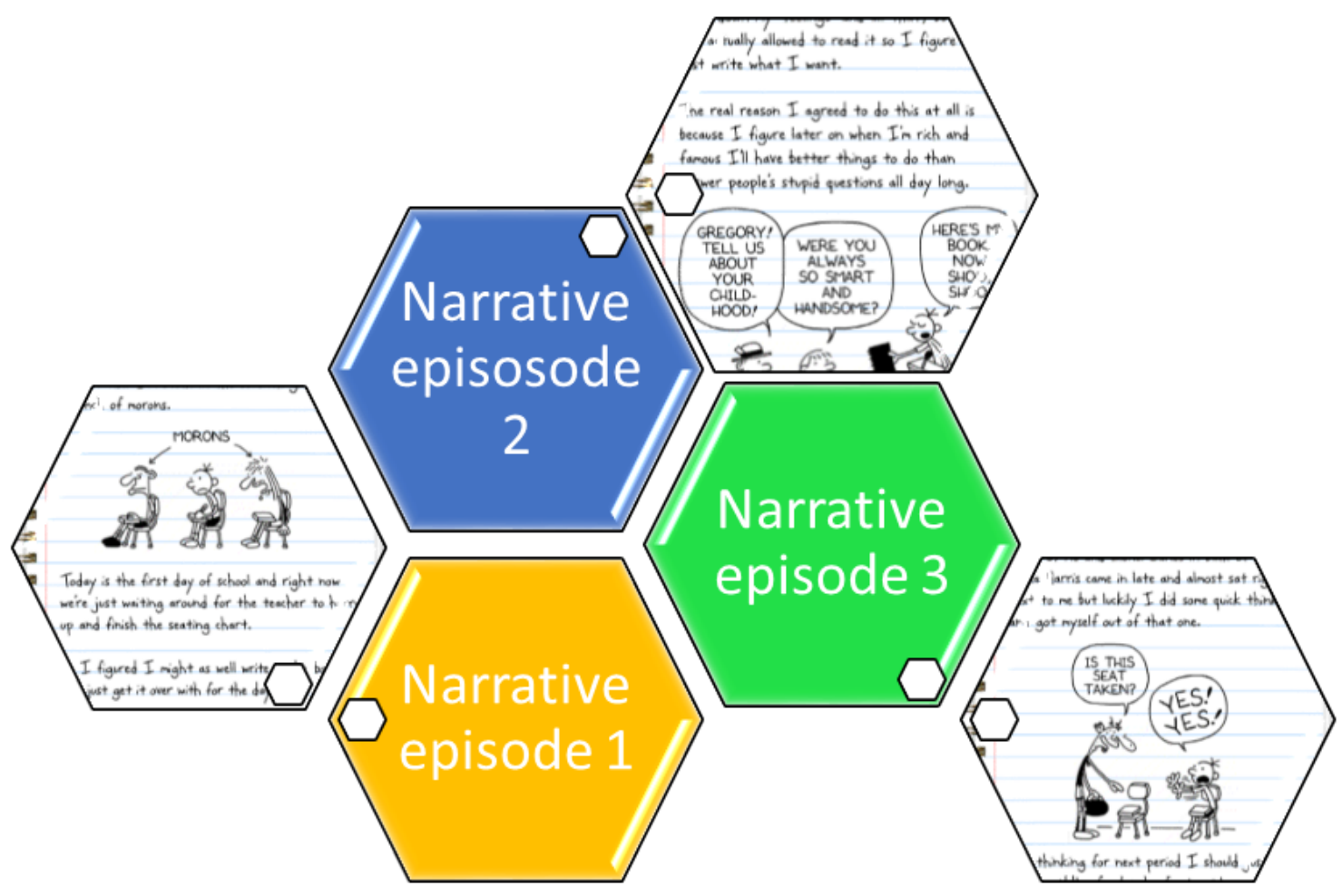

Fig. 4. Jigsaw puzzle model of narration

\footnotetext{
${ }^{17}$ Herman L., Vervaeck B. Handbook of narrative analysis. Lincoln and London : University of Nebraska Press, 2001. P. 33.

${ }^{18}$ Macmillan essential dictionary. Oxford : Bloomsbury Publishing Plc, 2003. P. 388.
} 


\section{Ethnonarrative theory for Australian fairy tales}

The development of Australian children's literature is closely connected with the history of Australian continent. It is believed, that first aboriginal tribes migrated from the European continent to Australia more than sixty thousand years ago. Those were people, who came via South Asia and settled on the Australian continent. This historical fact proves that Australian aboriginals have the longest cultural history of all the ever existed group of people ${ }^{19}$. All Australian myths and legends are connected with the land and place of their habitation, its Bush forests, rivers, deserts and long serpent paths. First Europeans, who came to live on the continent in the $18^{\text {th }}$ century, were penal colonists, who knew nothing about their new land of habitation and tried to explore and discover the territories. This period is characterized by difficult years of assimilation and adaptation. Indigenous Australians were much oppressed by Europeans, who controlled the country and tried to impose their rules. As a result, aboriginal tribes moved to the center of the continent to their native Bush zone, which they called Homeland. Native land has always been a special space both for indigenous people and mythological, legendary and fairy characters. All narratives of Aboriginal people of Australia are anchored in the Dreamtime, ever existing sacred period of yesterday-today-tomorrow life. It is believed, that Dreamtime is a network Universe, a complex of believes, knowledge, history, faith that exists in each cell of spiritual and physical life of Aboriginal Australians, who believe that Ancestor Spirits created all forms of life: humans and fauna, flora and natural elements ${ }^{20}$. The main Australian aboriginal cultural artifact of all times, including Dreamtime, is Boomerang. Boomerang, a hardwood club, became emblematic of Aboriginality. Best known of all is the so-called returning boomerang, a boomerang that when thrown by a skilled practitioner carves an elliptical trajectory in its return to the thrower. Firstly, it served as a weapon for hunting and protecting from enemies, it was also used for playing games and dancing ritual dances ${ }^{21}$. Irrespective of their purpose, nearly all boomerangs were augmented with painted and/or incised designs on their upper surface. As with most Aboriginal designs, these designs on boomerangs were not simply decorative but were also invocations of Dreaming ancestors, identity markers, such as clan or moiety membership,

\footnotetext{
${ }^{19}$ The Greenwood encyclopedia of folktales and fairy tales / edited by Donald Haase Westport Connecticut. London : Greenwood press 2008. P. 82-86.

${ }^{20}$ Historical dictionary of Australian aborigines / Mitchell Rolls, Murray Johnson ; introduction by Henry Reynolds. The Scarecrow Press, Inc. Lanham. Toronto. Plymouth, UK, 2011. 213 p. Clancy L. Culture and customs of Australia. Westport, Connecticut. London: Greenwood Press, 2004. 191 p. Flood J. The original Australians. Story of the Aboriginal people. Allen\&Unwin, 2006. 306 p.

${ }^{21}$ Historical dictionary of Australian aborigines / Mitchell Rolls, Murray Johnson ; introduction by Henry Reynolds. The Scarecrow Press, Inc. Lanham. Toronto. Plymouth, UK, 2011. P. 39.
} 
and/or indications of affiliation with local territory. Boomerangs and their symbolic circular trajectory (circular movements, returning to their master, sacred sense in the circle trajectory) had social and religious significance too.

All this knowledge and believes are preserved in Australian myths, legends, fairy tales and other forms of narratives. To explain the idea of special fairy narrative, constructed by Australian writers, we need to define basic theoretical and methodological issues. In our research we suggest the term fairy ethnonarrative which we consider specially construed and narrated only in Australian fairy narratives.

Fairy ethnonarrative - is a story about fictional world in verbal and verbal-visual medium, the narrative elements of which have ethnocultural specificity. In the center of the story are anthropomorphic characters koalas, wombats, Gumnut babies, who we define as ethnocharacters. Fairy ethnocharacters are existentially anchored in Bush space and Dreaming time, which in our research we understand as ethnochronotope. Fairy ethnocharacters and ethnochronotope exist only inside Australian fairy world, all these narrative elements have no analogs in fairy narratives of other linguistic cultures. Implicative characteristics of ethnorealia Boomerang (circular movements, home returning) underpin the plot and composition structure of Australian fairy ethnonarratives

In our research we shall illustrate the implementation of our hypothesis as for the ethnospecific nature of Australian fairy narratives on the basis of two most popular literary texts for children in Australia "Snugglepot and Cuddlepie",22, written by May Gibbs anda fairy narrative "The Magic Pudding", written by Norman Lindsay.

May Gibbs, an Australian writer, moved to Australia from Great Britain when she was a child. Her fairy Bush-characters are absolutely unique creatures, they are nuts of a Gumnut tree (Fig. 5), who live peacefully in the Bush with other bush-creatures: Blossoms and Nuts, $\mathrm{Mr}$. Kookaburra, Mr. Blue-cap Wren, Cicadas, Mrs.Funtail, Mr. Lizard, Mrs. Snake, Native Bears (Koalas), etc. One day Gumnut babies Snugglepot and Cuddlepie decide to have a journey in order to see a mysterious creature, a Human. All the events in the story as if develop round the circle, the adventures imitate boomerang trajectory: Gumnut babies get into a trap and are saved by their helpers, meet obstacles and get rid of them. In the first narrative episode Snugglepot and Cuddlepie are in the Bush with their friends, then they make a long quest-journey and come back again to their native Bush forests where they feel happy and safe (last episode). So, the first and the last narrative episodes correlate in their chronotope (Gumnut

\footnotetext{
${ }^{22}$ Gibbs M. Complete adventures of Snugglepot and Cuddlepie. Angus\&Robertson, 2010. 224 p.
} 
tree, Bush forest), characters (Snugglepot and Cuddlepie with Bush Blossoms and nuts) and message: "Bush is Homeland".

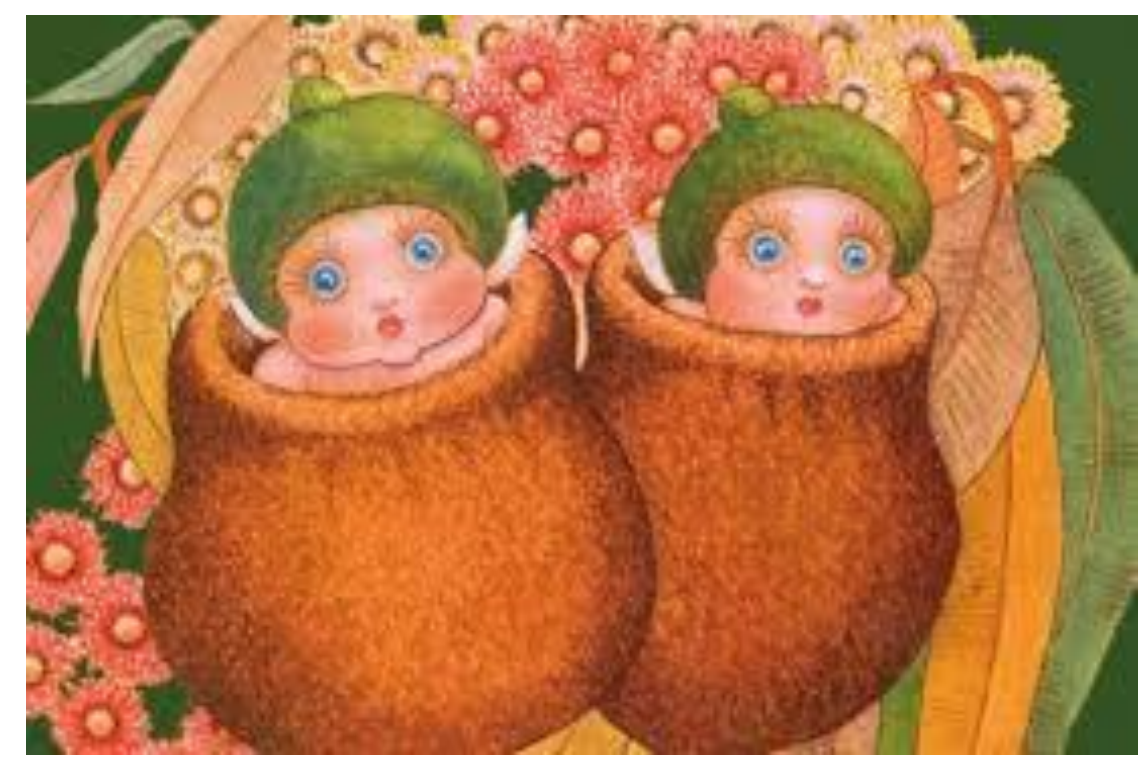

Fig. 5. Ethnocharacters of May Gibb's fairy narrative. Gumnut babies Snugglepot and Cuddlepie

On the lexical level, circular boomerang adventures are realized via verbs of motion: crept out of bed and out of the house; Then they began their journey; Then come, they flew;...was wandering, hastily ...came; Presently he came back with two lovely eggs; ride; they went along and soon became very good friends;They were travelling; Mr. Lizard returned; Without waste of time they all hurried up and the bed of the creek till they came to a deep pool; Mr Frog led the way along a dark passage; Presently they came to a large opening into another cave; $\mathrm{Mr}$ Lizard ...dashed up and out of the cave; After travelling a very long way through winding passages; Let's take a cab and drive round; It was a splendid ride; So they got abroad the Cab again and drove on; Let's walk a little way; Cuddlepie scrambled, and pushed, and tore his way through the sticks, and leaves, and ferns till he came to an open space at the foot of a big tree; Cuddlepie followed...till by and by he came to a little stream; Running after her; Came hurrying ...were running; Walked away through the Bush; They were at last on the road again; They went along; So they went back ${ }^{23}$.

Fictional time and space in the fairy narrative is defined as ethnochronotope, as it embodies realia of Australian flora. All the events in the abovementioned fairy narrative happen in the Bush. Bush space is embraced in various visual narrative episodes:

\footnotetext{
${ }^{23}$ Gibbs M. Complete adventures of Snugglepot and Cuddlepie. Angus\&Robertsen. 2010. 224 p.
} 


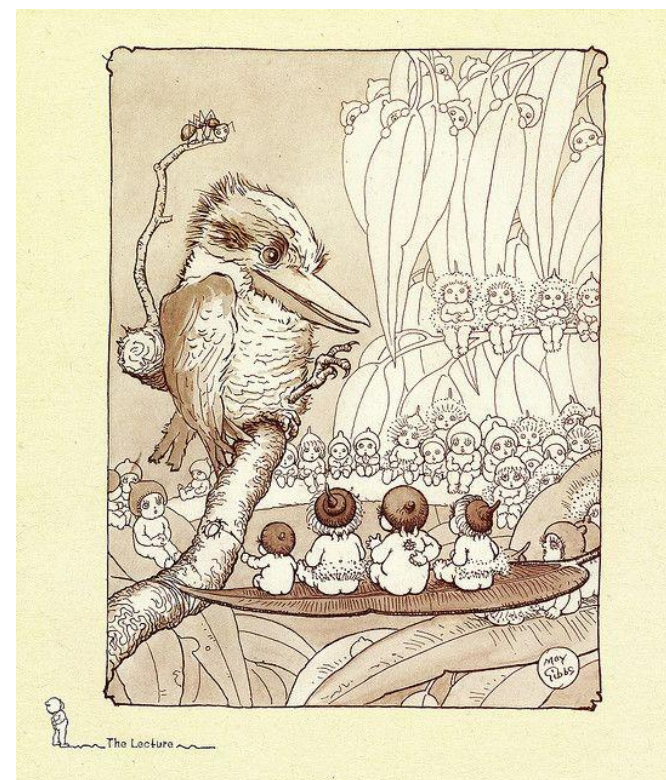

\section{Fig. 6. Kookaburra's lecture for Nuts and Blossoms in the Bush}

Bush space is represented as a contemporary zone, having both bush and rural facilities: bush-shop (So they went in and bought two biggest hats in the shop), second-hand goods (Snugglepot and Cuddlepie bought two little secondhand houses from a wayside shop), swimming-pool (the diving pool), bush-highways (busy highway), parties (Mrs Kookaburra's dinner party), bush- police officers (... a big Grey Possum on his road...They are policemen at night time because they can see in the dark), bush-editors (There, they were surprised to see an Editor writing all about them in his newspaper). There is even a bush cab-stand with unique Kangaroo cabs (Fig. 7).

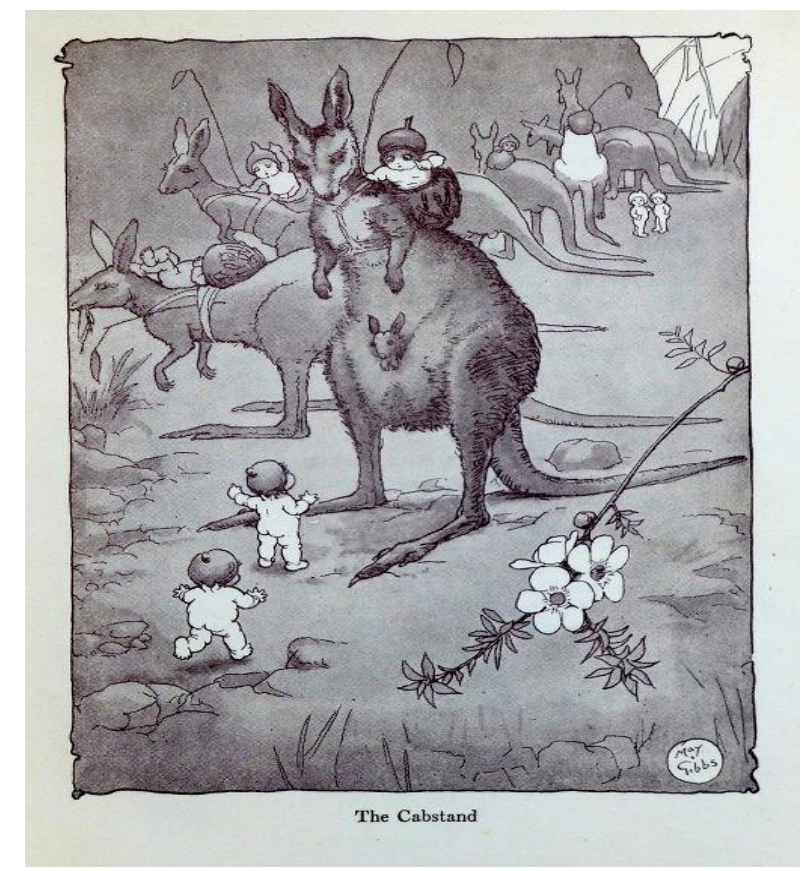

Fig. 7. Bush cab-stand 
In Australian fairy tale "The Magic Pudding" 24 written by Norman Lindsay fairy characters are anthropomorphic Bush-characters (ethnocharacters): koala bear Bunyip Bluegum (Fig. 8), Bill Barnacle, the sailor, and his friend, Sam Sawnoff, the penguin. The plot of the fairy tale: two bears live on a tree, Uncle and his nephew Bunyip. One day Bunyip decides to set off to see the world. On his way he meets two friends and a Magic Pudding named Albert, a character with anthropomorphic features. Albert talks, sings, grumbles, and wants to be eaten. Three friends call themselves "Noble Society of Pudding Owners" and travel all over the country to have adventures and joy. They are often attacked by sly thieves - a possum and a wombat, who want to steal this Magic pudding Albert.

The plot develops as if it is going round the circle. When the reader tastes his first slice, Bunyip meets his friends and the magic pudding: "...he discovered two people in the very act of having lunch... they had pudding in a basin). In the second slice the magic pudding named Albert is stolen and then found: "Bunyip Bluegum glanced back in time to see the Wombat in the act of stealing the Puddin' from the hollow log"; "The three friends had Puddin' rescued in no time, and shook hands all around, congratulating Bunyip Bluegum on success of his plan (The Magic Pudding, Second slice); In the next slice events repeat i.e. pudding Albert is stolen by a wombat and a possum: "The worst of it was that the Puddin', being too short to look in, was left outside, and the pudding'-thieves grabbed him at once and ran off like winking (The Magic Pudding,Slice three); and then found by his owners under the hat of the wombat "Hats of in honour of our King", shouted Bill, and off came all the hats. The Puddin'-thieves, of course, were helpless. The Wombat had to take his hat off, or prove himself disloyal, and there was found the Puddin' sitting on his head (The Magic Pudding, Slice three).

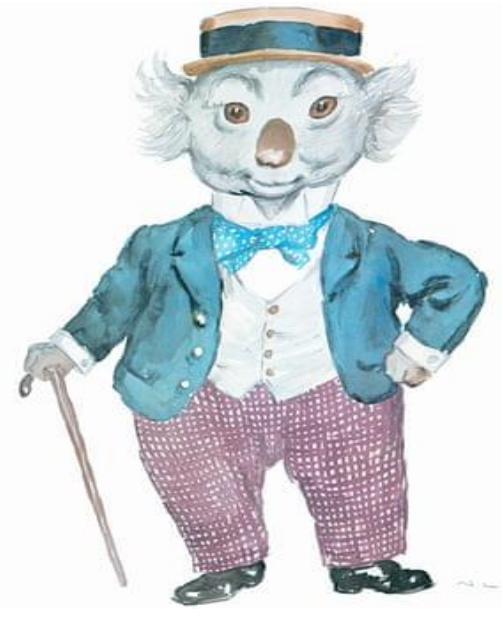

Fig. 8. Ethnocharacter Bunyip Bluegum of Norman Lindsay's fairy narrative "The Magic Pudding"

\footnotetext{
${ }^{24}$ Lindsay N. The Magic Pudding. Sydney : Angus\&Robertson, 2010. 171 p.
} 
The events, depicted in the fairy tale, are funny and are repeated one after another reminding a circle. Such composition and plot activate the knowledge of a child about the game Merry-go-round and a child gets involved into the plot and becomes interested in the characters of the fairy tale.

On the lexical level the semantics of circular movements is embodied in the lexical units with the meaning of movement all through the text, on the grammatical level circular movement is reflected via verbs of movement. According to Kubryakova's theory ${ }^{25}$, about the cognitive nature of the parts of speech, any information, any piece of world, can be realized via three categories. The information, which is realized via the category of action is actualized in speech by means of the motion verbs. Merry-goround is a dynamic play, it requires movements, fast actions, activity : the Puddin' got out of his basin, remarking-"If you won't eat any more here's giving you a run for the sake of exercise," and he set off so swiftly on a pair of extremely thin legs that Bill had to run like an antelope to catch him up".../... For, as everyone knows, running with the reel is one of the grand joys....... Bill, distracted with rage, ran after the Possum, then changed his mind and ran after the Wombat, so that, what with running first after one and then after the other.../..."On a terrible quest we run north-west, In a terrible rage we run; With never a rest we run northwest. Till our terrible work is done. Without delay. Away, away, In a terrible rage we run all day ${ }^{26}$.

Narrative activating words (verbs of movement/circular movement), composition structure (repetition of narrative episodes, correlation of initial and final episodes), the semantics of circular movement, which serves as a background of chaining events underlying a story enable us to reconstruct and then to design a model of narration which we define as Merry-go-round model. The semantics of the name of the model of narration is learned from different thesaurus sources: etymological, synonymous and definitional. It shows up as something that turns round: Merry-go-round is a machine with models of animals that children ride on as it turns round ${ }^{27}$; 1 . A revolving machine with models horse or cars on which people ride for amusement; 2. A continuous cycle of activities. The etymology of the word: merry comes from the old English word myrige, myrge and means pleasant and brief $^{28}$. The definition of the nominative unit Merry-go-round enables us to

\footnotetext{
${ }^{25}$ Кубрякова Е.С. Части речи с когнитивной точки зрения. М. : Институт языкознания РАН, 1997. $326 \mathrm{c}$.

${ }^{26}$ Lindsay N. The Magic Pudding. Sydney : Angus\&Robertson, 2010. 171 p.

${ }^{27}$ Macmillan essential dictionary. Oxford : Bloomsbury Publishing Plc, 2003. P. 452.

${ }^{28}$ A short etymological dictionary of modern English. London \& New York : Rouledge. Taylor and Francis group, 1996. P. 1968.
} 
reveal the most typical features of the word and main characteristics of the game itself. So, it follows that Merry-go-round is a pleasant and funny for children game, it moves round, has circular movements.

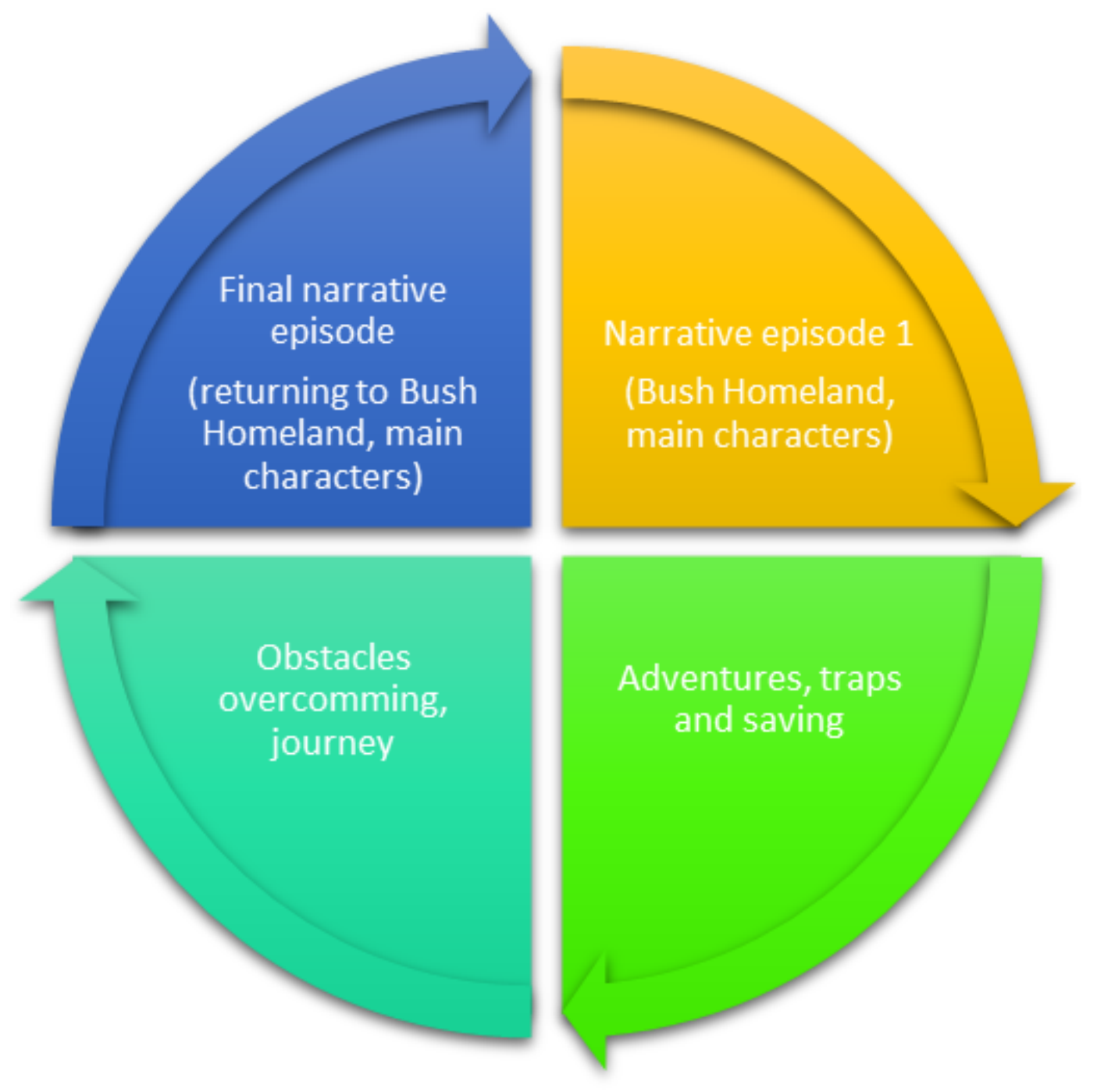

Fig. 9. Model of narration Merry-go-round

\section{CONCLUSIONS}

Narrative unfolds into two basic constituents: narrative as a story and narration as the way and result of construing this story. It has been revealed that the matrix, which underlies fairy narratives for children, is a gamemodel matrix. Curiosity and brainteasers are the key narrative storybuilding elements, which are hidden in the plot of a fairy narrative. Fairy narratives for children are construed in such a way, that definite narrative (chronotope, characters, events of the story) and narrational (composition structure, key-words in narrative episodes) triggers activate in a child's mind his/her knowledge about the game and make him/her immerse in the text. The narratological analysis of American and 
Australian literary texts for children enabled us to reconstruct and to design two basic models of narration which we define as Jigsaw puzzle model and Merry-go-round model. It has been proved, that fairy narratives of different linguistic cultures have different matrix models of narration which reflect the specificity of a certain linguistic culture. The paper suggests the definition of the term fairy ethnonarrative, which we understand as a story about fictional world in verbal and verbal-visual medium, the narrative elements of which have ethnocultural specificity. In the center of the story are anthropomorphic characters - koalas, wombats, Gumnut babies, who we define as ethnocharacters. Fairy ethnocharacters are existentially anchored in Bush space and Dreaming time, which in our research we understand as ethnochronotope. Fairy ethnocharacters and ethnochronotope exist only inside Australian fairy world, all these narrative elements have no analogs in fairy narratives of other linguistic cultures. Implicative characteristics of ethnorealia Boomerang (circular movements, home returning) underpin the plot and composition structure of Australian fairy ethnonarratives

\section{SUMMARY}

The paper focuses on the problem of narrative modelling of literary texts for children of the American and Australian linguistic cultures. Following Propp's theory about fairy folktales patterns, we have created a matrix model that enabled both to explain author's intentions and strategies, implemented in the text, and give methodological tool to make appropriate interpretation of the fairy narrative. It is assumed that there exist certain patterns which serve as a universal matrix, as they underlie a fairy tale of a definite linguistic culture. To understand cultural specificity of fairy narratives modelling, we have researched both the text narrative structure and its wide context (all extralinguistic factors that influenced its creation). Case study of the research are Australian fairy narrative "Snugglepot and Cuddlepie" written by May Gibbs, "The Magic Pudding" written by Norman Lindsay and American diary-format narratives for children "Diary of a Wimpy Kid", written by Jeff Kinney.

Narratological analysis enabled us to reconstruct and model two matrix patterns which we define as Jigsaw puzzle model and Merry-goround model.

In Jigsaw puzzle narrative modelling a story is split into various narrative episodes. Each fragment represents some episode of main character's life. Putting together all these episodes like jigsaw puzzle elements, a reader can comprehend an entire life story of the hero. 
Merry-go-round model presupposes repetition of the events, represented in narrative episodes of the fairy narrative. Initial and final narrative episodes correlate in chronotope and characters.

\section{REFERENCES}

1. Выготский Л.М. Психология развития ребенка. Москва: Смысл; Эксмо, 2004. 512 с.

2. Женетт Жерар Фигуры. М.: изд-во им. Сабашниковых, 1998.944 c.

3. Література. Теорія. Методологія / за наук. ред. Данути Уліцької. Київ: Видавничий дім “Києво-Могилянська Академія". 2008. C. 219-225.

4. Пропп В. Морфология сказки. Ленинград: “Аcademia”, 1928. $152 \mathrm{c}$.

5. A short etymological dictionary of modern English. London \& New York: Rouledge. Taylor and Francis group, 1996. P. 1968.

6. Beauvais C. The mighty child. Time and power in children's literature. Amsterdam: Publishing company, 2015. 226 p.

7. Clancy L. Culture and customs of Australia. Westport, Connecticut. London: Greenwood Press, 2004. 191 p.

8. Diary of a Wimpy Kid. URL: https://www.funbrain.com/books/ diary-of-a-wimpy-kid (дата звернення 25.09.2019).

9. Diary of a Wimpy Kid. About the author. URL: https://wimpykid.com/about-the-author/_(дата звернення 25.09.2019).

10. Flood J. The original Australians. Story of the Aboriginal people. Allen\&Unwin, 2006. 306 p.

11. Gibbs May The complete adventures of Snugglepot and Cuddlepie. Angus\&Robertson, 2010. 224 p.

12. Glazer J., Gurney Williams III Introduction to children's literature. New York: McGraw-Hill, 1979. 737 p.

13. Fludernik M. An introduction to narratology. London and New York: Rouledge. Taylor and Francis group, 2002. 190 p.

14. Historical dictionary of Australian aborigines / Mitchell Rolls, Murray Johnson; introduction by Henry Reynolds. The Scarecrow Press, Inc. Lanham. Toronto. Plymouth, UK, 2011. 213 p.

15. Herman L., Vervaeck B. Handbook of narrative analysis. Lincoln and London: University of Nebraska Press, 2001. 232 p.

16. Kinney Jeff Diary of a Wimpy Kid. England: Puffin, 2010. 218 p.

17. Kukkonen K. Contemporary comics storytelling. Lincoln and London: University of Nebraska Press, 2013. 231 p. 
18. Lindsay N. The Magic Pudding. Sydney: Angus\&Robertson, 2010. $171 \mathrm{p}$.

19. Macmillan essential dictionary. Oxford: Bloomsbury Publishing Plc, 2003. P. 388, 452.

20. Morphology of the Folktale by V. Propp / revised and edited by Louis A.Wagner. Austin: University of Texas Press, 20019. P. 21.

21. Palmer Allan Fictional minds. Lincoln and London : University of Nebraska Press, 2004. 276 p.

22. Shavit Z. Poetics of Children's literature. Athens and London : The University of Georgia Press, 1986. 193 p.

23. The Greenwood encyclopedia of folktales and fairy tales / edited by Donald Haase Westport Connecticut. London : Greenwood press 2008. P. $82-86$

24. Toolan Michael Making sense of narrative text. Situation, repetition, and picturing in the reading of short stories. Taylor and Francis Ltd., 2016. 284 p.

\author{
Information about the author: \\ Tsapiv A. O., \\ Candidate of Philological Sciences, \\ Associate Professor at the Department of Translation Studies \\ and Applied Linguistics, \\ Postdoctoral Student at the Department of the English Language \\ and Methodology of its Teaching, \\ Kherson State University \\ 27, Universytetska str., Kherson, 73000, Ukraine
}

